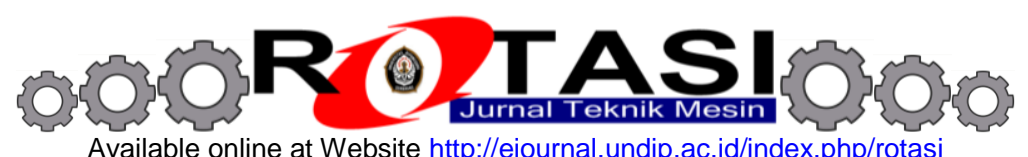

\title{
PENGARUH TEMPERATUR TERHADAP SIFAT FISIK MEKANIK PADA SAMBUNGAN DIFUSI LOGAM TAK SEJENIS ANTARA SS400 DENGAN Al6061
}

\author{
*Agus Hadi Hariyanto ${ }^{a}$ Triyono $^{b}$, Agus Supriyanto ${ }^{c}$ \\ ${ }^{a}$ Mahasiswa Program Magister Teknik Mesin Universitas Sebelas Maret \\ burusan Teknik Mesin, Fakultas Teknik, Universitas Sebelas Maret \\ ${ }^{\mathrm{c}}$ Jurusan Teknik Fisika, Fakultas MIPA, Universitas Sebelas Maret \\ Jl. Ir. Sutami 36 A Kentingan Surakarta 57126 \\ *Email:mazagushadi@yahoo.co.id, triyonomesin@uns.ac.id
}

\begin{abstract}
Diffusion welding on the disimilar metal between steel SS400 and aluminum Al6061 by using induction furnace, the temperature variation and filler variation. Temperature variations that are used $850^{\circ} \mathrm{C}$, $875^{\circ} \mathrm{C}$ and $900^{\circ} \mathrm{C}$. Filler that is used $\mathrm{Fe}$ and $\mathrm{Cu}$ powders, in variations filler $\mathrm{Fe} / \mathrm{Cu}: 70 / 30 \%, 75 / 25 \%$, $80 / 20 \%$, on 30 minutes holding time. The results shows there is the presence of intermetallic layers in the temperaturs. Results of Scanning Electron Microscop (SEM), good diffusion process occurs on temperatures $850^{\circ} \mathrm{C}$ and filler variations $\mathrm{Fe}: 75 \%, \mathrm{Cu}: 25 \%$. It occurs interface bonding steel and aluminum on diffusion area. Interface bonding steel and aluminum will produces intermetalic layer $\mathrm{Fe}_{2} \mathrm{Al}_{3}$. The results of good hardness distribution occurs on $900{ }^{\circ} \mathrm{C}$ filler variations $\mathrm{Fe}: 75 \%, \mathrm{Cu}: 25 \%$. It occurs intermetalic layer formation on diffusion area. Intermetalic layer formation is influenced by heat treatment and diffusion of $\mathrm{Fe}$ atoms and $\mathrm{Cu}$ atoms. The higher the heat treatment, the harder the $\mathrm{Cu}$ atoms. So it will affect the hardness intermetalic layer. By the higher heat treatment, the microstructure of the coating intermetalic will be so close. The more tightly layered arrangement intermatalic blistering effect on shear test. The results of tensile shear testing, high voltage value occurs on $900^{\circ} \mathrm{C}$ filler variations $\mathrm{Fe}: 75 \%$, Cu: $25 \%$. It is influenced by a continuous heating process, thus causing the $\mathrm{Cu}$ atoms will be hard. With high heat, Fe atoms will diffuse to the base metal aluminum and copper atoms will diffuse to the base metal and Al6061 SS400. So that the Fe and Cu atoms will bond with the base metal that affects the mechanical properties.
\end{abstract}

Keywords: Diffudion welding; Filler; Heat treatment; Intermetalic layer; Temperature

\section{PENDAhuluan}

Produsen perkapalan saat ini sangat tertarik untuk mengurangi berat massa dalam rangka meningkatkan kinerja dan penghematan bahan bakar. Dulal dan Yeong-do [1] mengatakan untuk meningkatkan kinerja dan penghematan bahan bakar dapat dilakukan dengan menurunkan berat massa. Berat massa yang menggunakan baja, dapat digantikan dengan bahan ringan seperti aluminum ( $\mathrm{Al}$ ), atau baja dikombinasikan dengan aluminium. Keuntungan menggunakan aluminium diantaranya adalah tahan korosi, tidak mempunyai daya magnet dan tidak ada perubahan warna selama proses pemanasan.

Rathod dan Kutsuna [2] mengatakan untuk meningkatkan kekuatan dapat di aplikasikan dengan menggabungkan paduan aluminium dengan baja. Paduan aluminium dan baja sulit disambung dengan proses pengelasan karena ada perbedaan titik leleh secara drastis. Titik leleh paduan aluminium adalah 933K sedangkan titik leleh baja adalah $1811 \mathrm{~K}$.

Metode Laser roll menggunakan variasi waktu, temperatur dan tekanan. Dengan mempelakukan tekanan yang tinggi maka dapat mempercepat timbulnya formasi senyawa intermetalik pada kedua material. Senyawa intermetalik, membuat sambungan kedua material rapuh [2].

Metode Resistance Spot Welding (RSW) menggunakan bahan transisi nugget aluminium berlapis strip baja, dengan mengoptimalkan kombinasi elektroda dan parameter pengelasan diketemukan bahwa dua zona yang berbeda fusi membentuk proses spot welding. Proses spot welding akan membentuk butiran struktur dendritik . Paduan baja dan aluminium akan terbentuk senyawa intermetalik akibat dari proses pengelasan [3]. Nugget aluminium berlapis strip baja sebagai lapisan transisi dapat digunakan dalam membentuk struktur lasan antara aluminum dengan baja [4].

Ranfeng qiu [5] mengatakan karakteristik antarmuka sambungan baja dengan aluminium dengan metode RSW, menunjukan reaksi dari Fe2A15 berdekatan dengan baja dan FeA13 berdekatan dengan paduan aluminium di wilayah tengah lasan.

Hasil uraian penelitian di atas menunjukan bahwa sambungan antara paduan aluminium dengan baja tidak mudah fusion di las sama-sama,karena adaya perbedaan titik leleh. Dengan adanya perbedaan titik leleh yang berbeda, penulis meriset ulang dengan metode yang berbeda. Metode yang digunakan adalah sambungan las difusi menggunakan furnace. Parameter sambungan las difusi yang digunakan variasi temperatur dan variasi filler serbuk $\mathrm{Ferro}(\mathrm{Fe})$ dan Copper $(\mathrm{Cu})$. 


\section{MATERIAL DAN METODOLOGI}

\subsection{Material dan Proses Difusi}

Pada penelitian ini material yang digunakan adalah baja karbon rendah SS400 dengan tebal $2.3 \mathrm{~mm}$, disambungkan dengan paduan Al6061 tebal 6 mm. Komposisi kimia baja SS400 dan aluminium Al6061 ditunjukkan pada Tabel 1, sedangkan sifat mekanik ditunjukkan pada Tabel 2

Tabel 1. Komposisi Kimia Baja SS400 dan Al6061 [10,11]

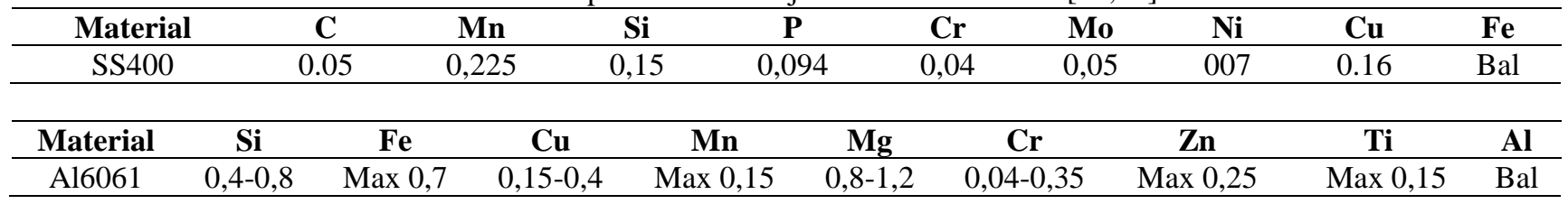

Tabel 2. Sifat Mekanik SS400 dan Al6061 [6,10]

\begin{tabular}{|c|c|c|c|c|c|}
\hline Material & $\begin{array}{c}\text { Titik } \\
\text { Leleh } \\
\left({ }^{\circ} \mathrm{C}\right) \\
\end{array}$ & $\begin{array}{c}\text { Daya Hantar } \\
\text { Panas } \\
(\mathrm{W} / \mathrm{mK}) \\
\end{array}$ & $\begin{array}{c}\text { Koefisien Panas } \\
\text { Ekspansi } \\
\left(\mu \mathrm{m} / \mathrm{m} /{ }^{0} \mathrm{C}\right) \\
\end{array}$ & $\begin{array}{c}\text { Kekuatan Tarik } \\
\text { (Mpa) }\end{array}$ & $\begin{array}{c}\text { Resistansi } \\
\text { listrik } \\
(\mu \Omega . c m) \\
\end{array}$ \\
\hline SS400 & $1495-1525$ & 12.6 & 13.0 & 240 & 2.65 \\
\hline Material & $\begin{array}{c}\text { Titik Leleh } \\
\left({ }^{\circ} \mathrm{C}\right)\end{array}$ & Panas Jenis $\left(\mathrm{J} / \mathrm{Kg}^{0}{ }^{0} \mathrm{C}\right)$ & Masss Jenis $\left(\mathrm{Kg} / \mathrm{m}^{3}\right)$ & $\begin{array}{c}\text { Daya Hantar Panas } \\
\left(\left(\mathrm{J} / \mathrm{m}^{3} .^{0} \mathrm{C} . \mathrm{s}\right)\right.\end{array}$ & $\begin{array}{c}\text { Resistansi listrik } \\
(\mu \Omega . c m) ~\end{array}$ \\
\hline Al6061 & 660 & 900 & 2700 & 220 & 2.65 \\
\hline
\end{tabular}

Proses pengelasan dilakukan dengan metode diffusion welding menggunakan alat furnace induksi, dengan variasi temperatur $850^{\circ} \mathrm{C}, 875^{\circ} \mathrm{C}, 900^{\circ} \mathrm{C}$ dengan holding time 30 menit. Proses pengelasan dilakukan dengan menggunakan penambahan filler serbuk $\mathrm{Fe}$ dan $\mathrm{Cu}$. Komposisi filler menggunakan fraksi volume dengan variasi $\mathrm{Fe}=70 \%, \mathrm{Cu}=30 \% ; \mathrm{Fe}=75 \%, \mathrm{Cu}=25 \% ; \mathrm{Fe}=80 \%, \mathrm{Cu}=20 \%$. Pencampuran filler dilakukan dengan proses mixing dengan kecepatan $270 \mathrm{rpm}$ selama 30 menit. Pendinginan dilakukan di dalam furnace

\subsection{Pengamatan Struktur mikro}

Baja karbon rendah SS400 dengan tebal $2.3 \mathrm{~mm}$, dan paduan Al6061 tebal $6 \mathrm{~mm}$ dipotong dengan ukuran 30mm x 30mm. Baja karbon rendah SS400 diperlakukan proses pemesinan milling dengan ukuran 20mm x 20mm, dengan kedalaman $1 \mathrm{~mm}$. Dimensi spesimen uji dapat di lihat pada Gambar 1.

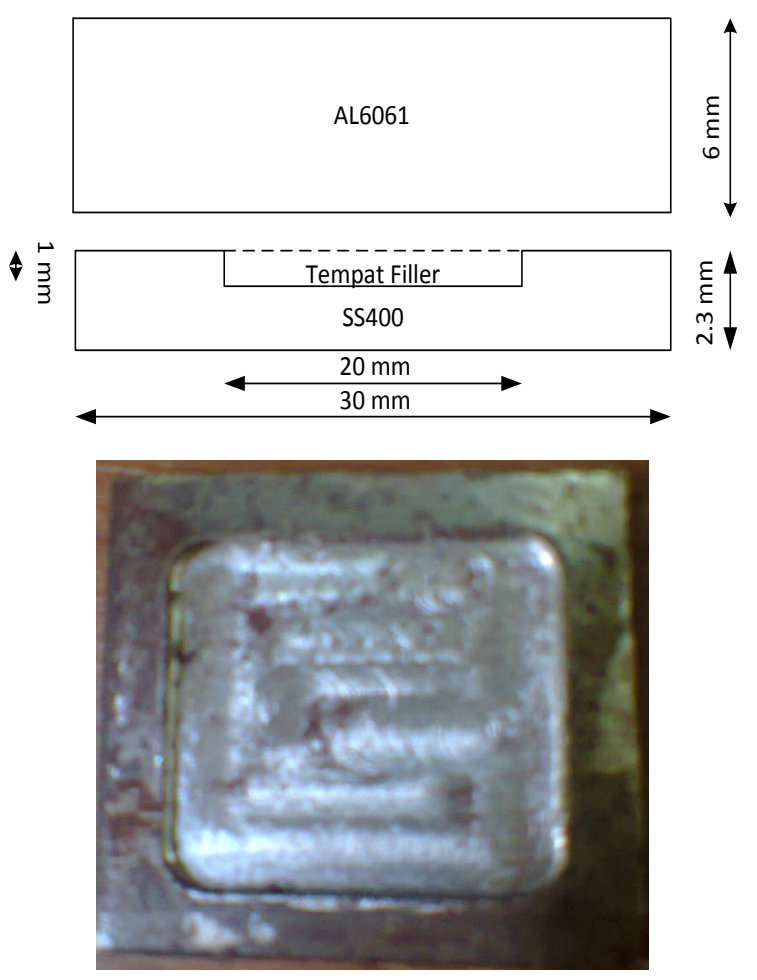

Gambar 1. Dimensi spesimen uji 
Setelah pendinginan dilakukan, spesimen dipotong dengan ukuran 10mmx10mm. Spesimen diamplas, dietsa untuk mendapatkan mikrostruktur. Untuk mendapatkan mikrostruktur interface dilakukan menggunakan mikroskop optik dan SEM (Scanning Electron Microscope).

\subsection{Proses Pengujian Kekerasan}

Pengujian kekerasan menggunakan vickers microhardnes. Pengujian dilakukan pada daerah logam induk dan daerah interface. Pengujian daerah baja karbon rendah SS400 menggunakan beban 200 grf. Pengujian daerah interface menggunakan beban 200 grf. Pengunjian daerah paduan Al6061 menggunakan beban 100 grf. Pengujian vickers microhardnes dilakukan untuk mengetahui distribusi kekerasan dari base metal ke intermetalic.

\subsection{Proses Pengujian Geser Tarik}

Pengujian mekanik yang dilakukan adalah pengujian geser tarik. Bentuk specimen terlihat pada Gambar 2

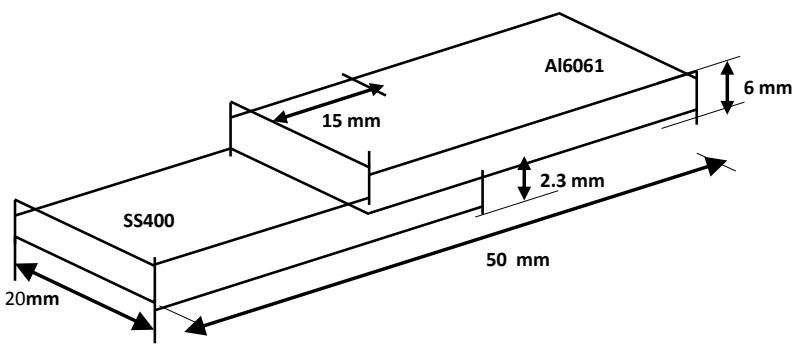

Gambar 2. Dimensi spesimen Uji Geser Tarik

\section{HASIL DAN PEMBAHASAN}

\subsection{Foto Makro}

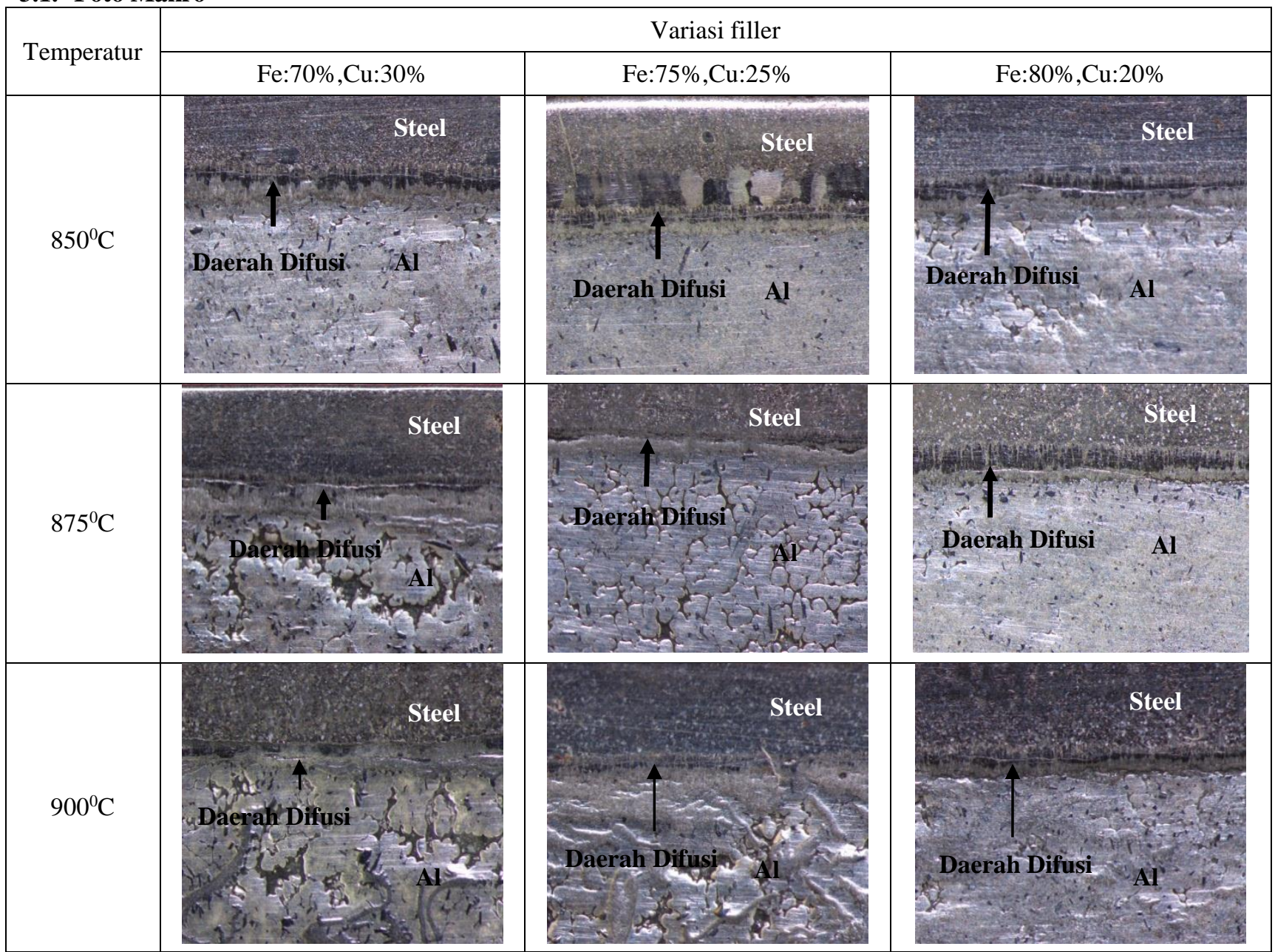

Gambar 3. Foto makro SS400 dan Al6061 
Pengamatan foto makro pada Gambar 3, memperlihatkan terjadinya difusi di daerah antarmuka baja dan aluminium , sehingga mengakibatkan kedua permukaan material saling berikatan. Pada daerah base metal aluminium Al6061 terlihat kekeroposan Kekeroposan disebabkan adanya perbedaan pengaruh panas pengelasan paduan aluminium. Pengaruh panas pengelasan paduan aluminium dapat menyebabkan pencairan sebagian, rekristalisasi, pelarutan padat atau pengendapan, tergantung pada tingginya suhu pada daerah las [16]. Sehingga mengakibatkan ikatan base metal aluminium Al6061 dengan filler tidak cukup baik.

\subsection{Foto Mikro}

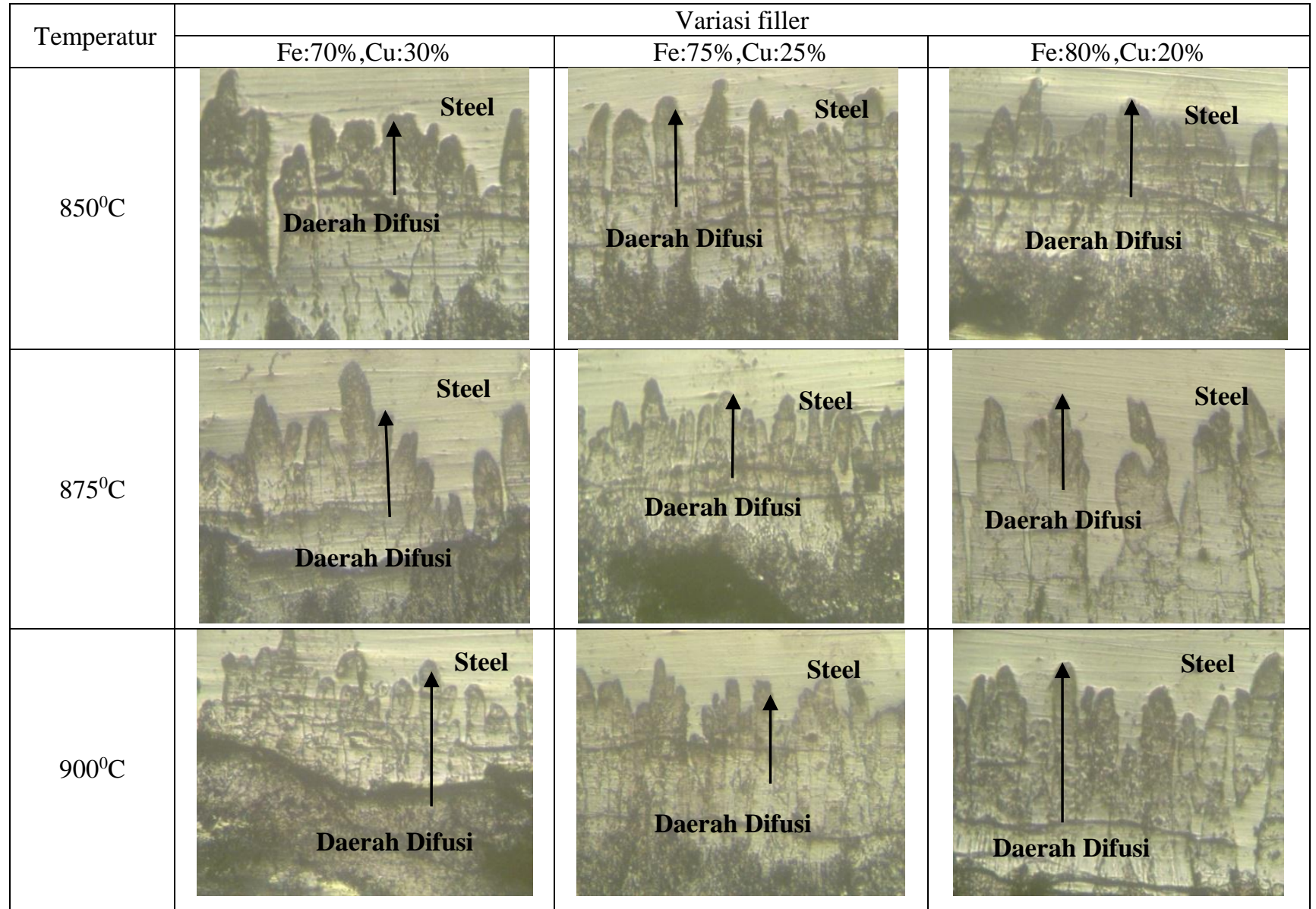

Gambar 4. Foto mikro SS400 dan Al6061

Pengamatan foto mikro pada Gambar 4, memperlihatkan terjadinya difusi di daerah antarmuka baja SS400 dengan aluminium Al6061, sehingga mengakibatkan alumunium terlarut di daerah baja. Semakin banyak jumlah atom Fe yang difusi di antarmuka, mengakibatkan ikatan antara baja dan aluminium akan semakin baik, sehingga homogenitas kedua material semakin baik.

3.3. SEM EDX

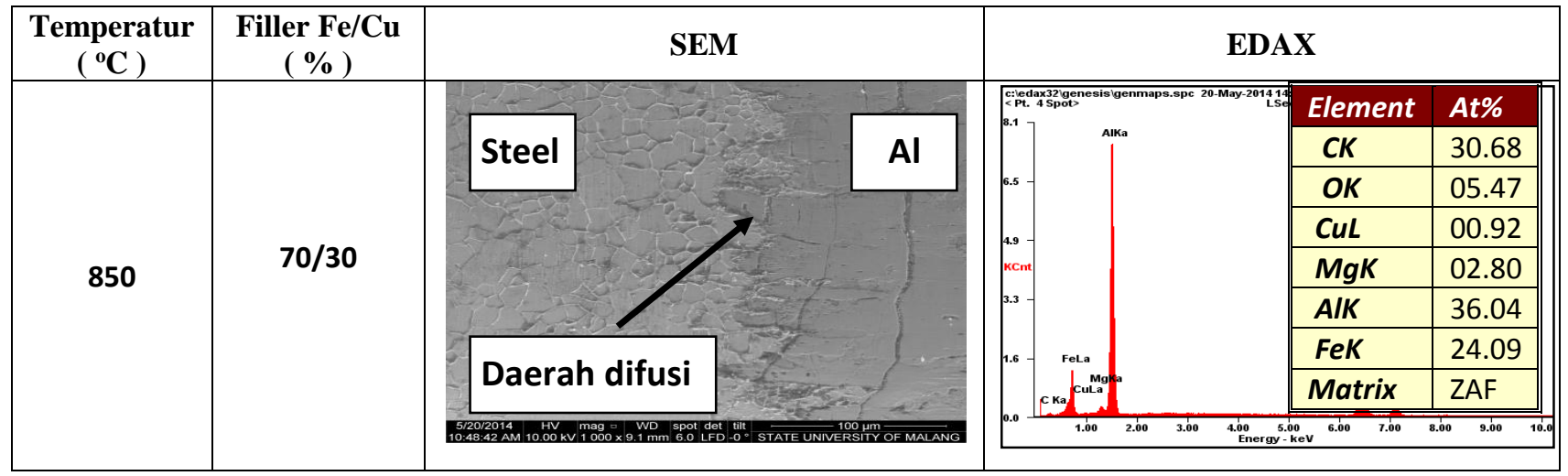




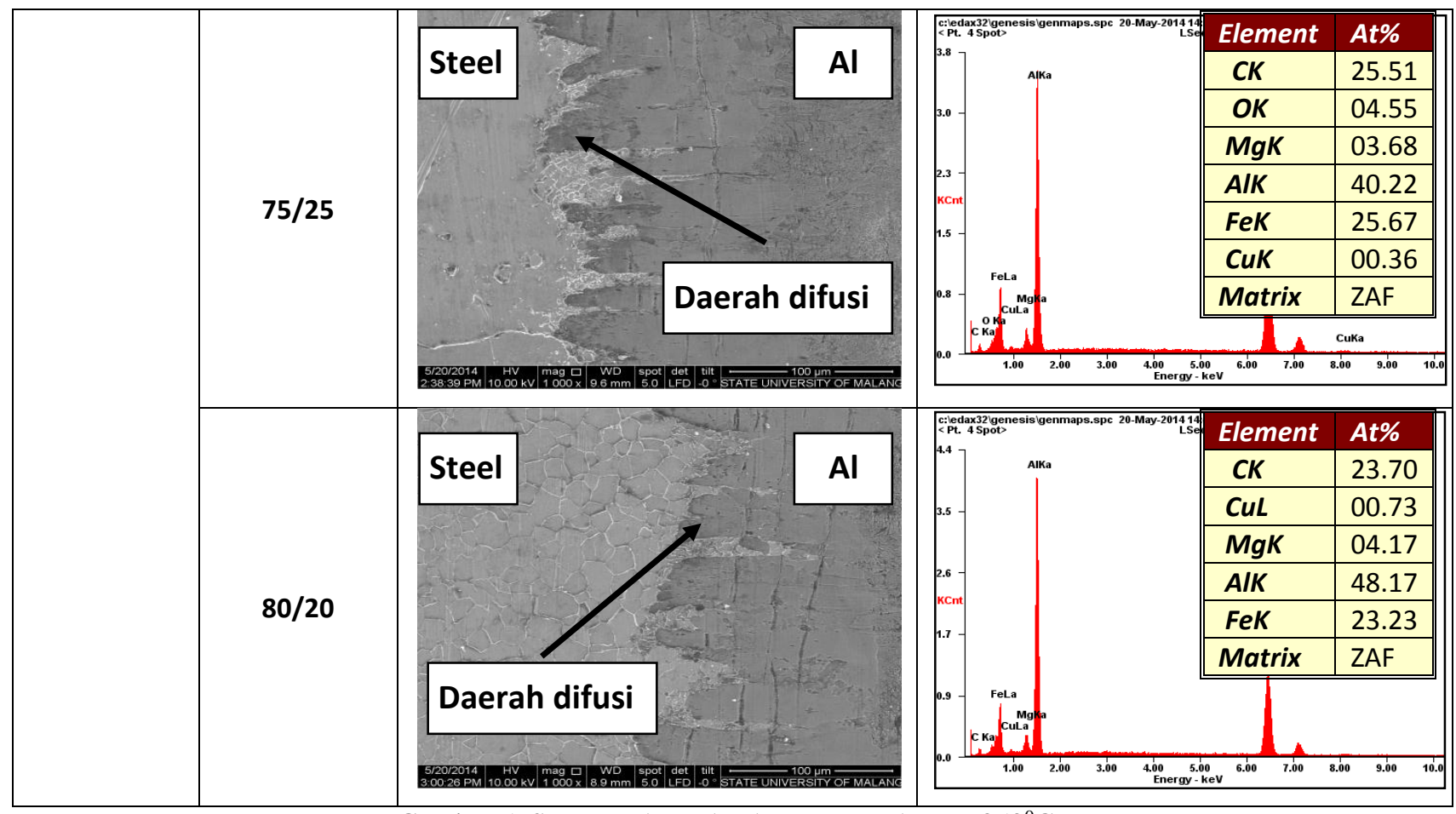

Gambar 5. SEM EDAX PADA TEMPERATUR $850^{\circ} \mathrm{C}$

Pengamatan SEM dan EDAX pada Gambar 5 memperlihatkan atom Al mengalami keterlarutan ke daerah Fe. Keterlarutan atom Al pada daerah Fe tidak mengalami perbedaan yang berlebih. Semakin banyak unsur Fe yang terlarut kedalam daerah Al, akan semakin baik. Keterlarutan atom Al pada daerah Fe dan sebaliknya, akan membentuk homogenitas pada kedua material, sehingga daerah antarmuka kedua material akan terjadi ikatan. Ikatan antarmuka aluminium dengan baja akan membentuk lapisan intermetalik. Pembentukan lapisan intermetalik dipengaruhi oleh temperatur dan variasi filler. Pada temperatur $850^{\circ} \mathrm{C}$ filler 70/30,75/25 membentuk lapisan intermetalik $\mathrm{Fe}_{3} \mathrm{Al}_{2}$, sedangkan filler 80/20 membentuk lapisan intermetalik $\mathrm{Fe}_{4} \mathrm{Al}$.

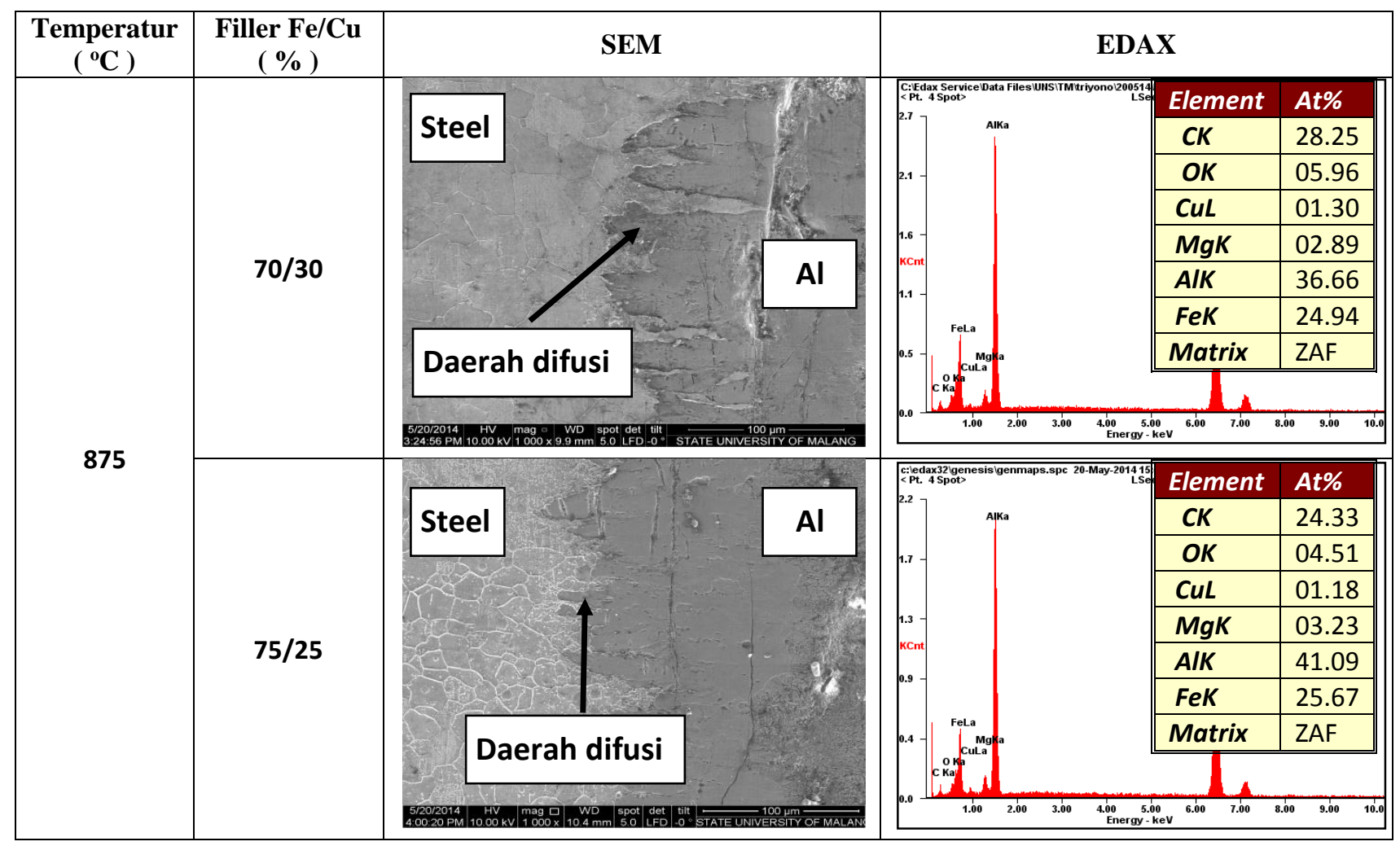




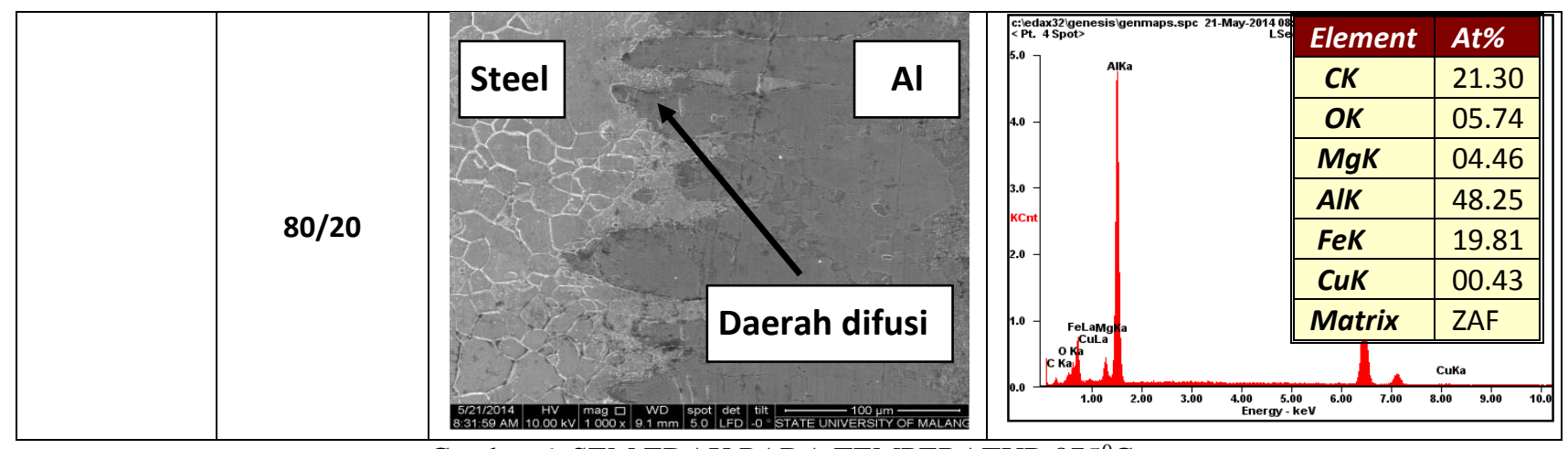

Gambar 6. SEM EDAX PADA TEMPERATUR $875^{\circ} \mathrm{C}$

Pengamatan SEM dan EDAX pada Gambar 6 memperlihatkan keterlarutan atom Al pada daerah Fe masih mendominasi. Keterlarutan atom Al pada daerah Fe dan sebaliknya, akan membentuk homogenitas pada kedua material, sehingga pada daerah antarmuka kedua material akan terjadi ikatan. Ikatan antarmuka aluminium dengan baja akan membentuk lapisan intermetalik. Pembentukan lapisan intermetalik pada temperatur $875^{\circ} \mathrm{C}$ filler $70 / 30,75 / 25$ adalah $\mathrm{Fe}_{3} \mathrm{Al}_{2}$, sedangkan filler 80/20 membentuk lapisan intermetalik $\mathrm{Fe}_{4} \mathrm{Al}$.

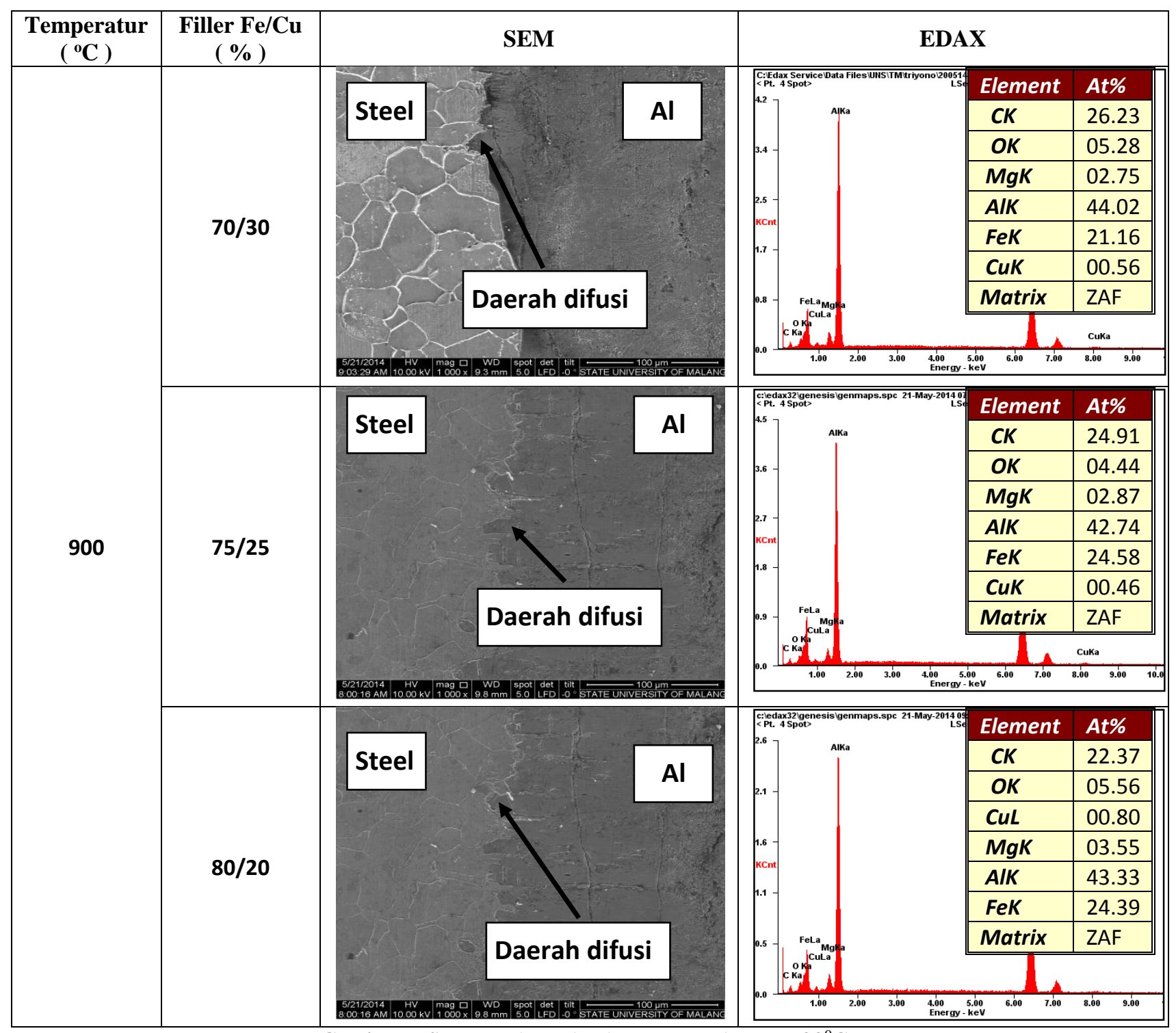

Gambar 7. SEM EDAX PADA TEMPERATUR $900^{\circ} \mathrm{C}$ 
Pengamatan SEM dan EDAX pada Gambar 7 memperlihatkan atom Al mengalami keterlarutan ke daerah $\mathrm{Fe}$. Keterlarutan atom $\mathrm{Al}$ pada daerah Fe tidak mengalami perbedaan yang berlebih terhadap temperatur $850^{\circ} \mathrm{C}$ dan $875^{\circ} \mathrm{C}$. Pembentukan lapisan intermetalik pada temperatur $900^{\circ} \mathrm{C}$ variasi filler 75/25,80/20 adalah $\mathrm{Fe}_{3} \mathrm{Al}_{2}$, sedangkan filler 70/30 membentuk lapisan intermetalik $\mathrm{Fe}_{3} \mathrm{Al}$

\subsection{Distribusi Kekerasan Pada Lapisan Intermetalik}
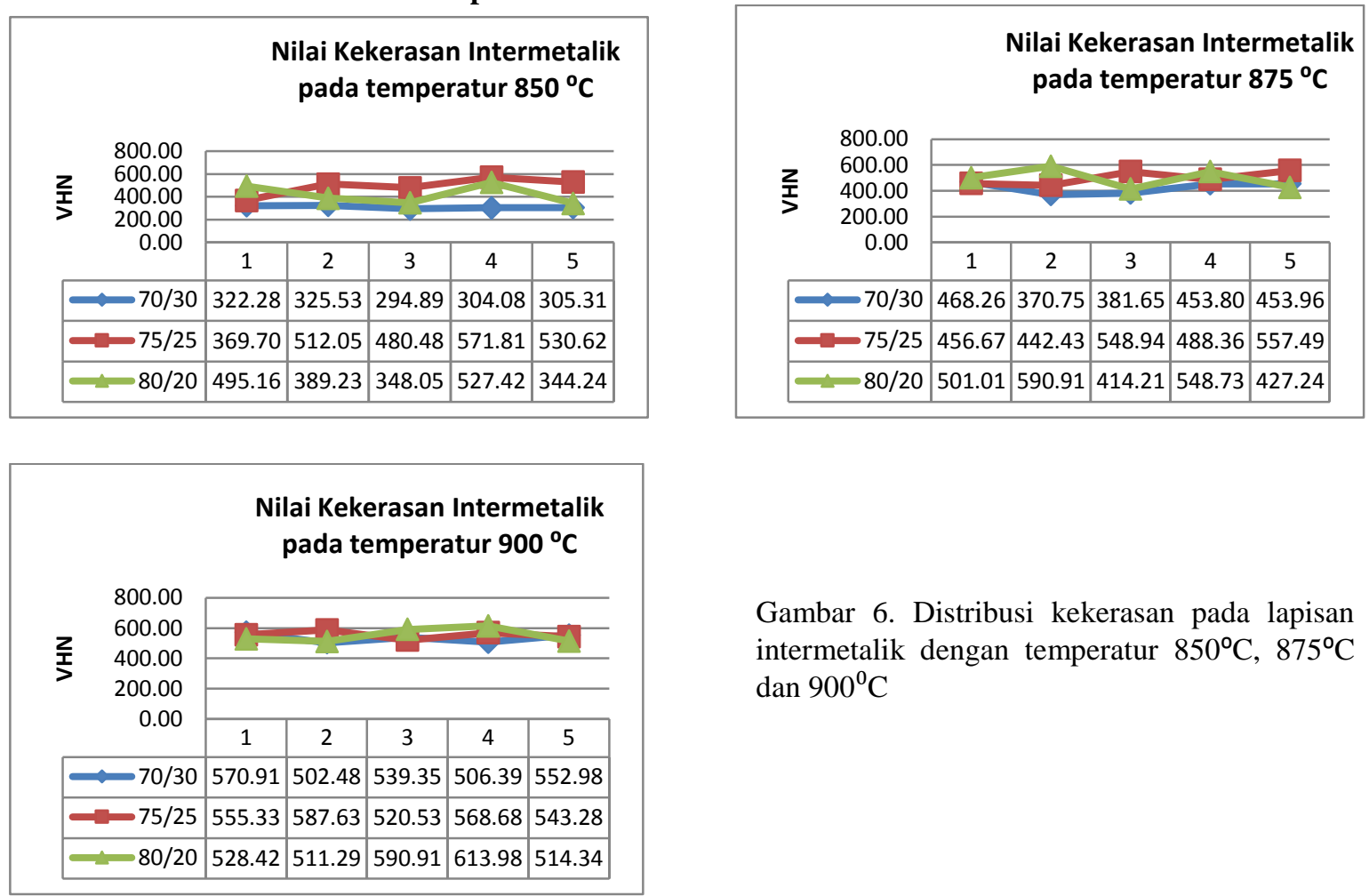

Gambar 6. Distribusi kekerasan pada lapisan intermetalik dengan temperatur $850^{\circ} \mathrm{C}, 875^{\circ} \mathrm{C}$ dan $900^{\circ} \mathrm{C}$

Nilai distribusi kekerasan pada lapisan intermetalik terlihat pada gambar 6. Pembentukan lapisan intermetalik berdasarkan diagram fasa $\mathrm{Al}-\mathrm{Cu}$, pada temperatur $850^{\circ} \mathrm{C}-900^{\circ} \mathrm{C}$ terjadi fase cair[15]. Pada saat fase cair terjadi difusi antara $\mathrm{Al}-\mathrm{Cu}$ dengan $\mathrm{Fe}$. Dengan holding time 30 menit, dimungkinkan difusi antara $\mathrm{Al}-\mathrm{Cu}$ dengan $\mathrm{Fe}$ semakin homogenitas (gambar 7). Pembentukan lapisan intermetalik berdasarkan diagram fase $\mathrm{Fe}-\mathrm{Fe}_{3} \mathrm{C}$, pada temperatur $850^{\circ} \mathrm{C}-900^{\circ} \mathrm{C}$ terjadi titik tranformasi terbentuknya ferrit dari austenit.[15]. Pada temperatur $850^{\circ} \mathrm{C}-900^{\circ} \mathrm{C}$ di antarmuka aluminum dan baja mulai terbentuknya ferrit dari austenit.

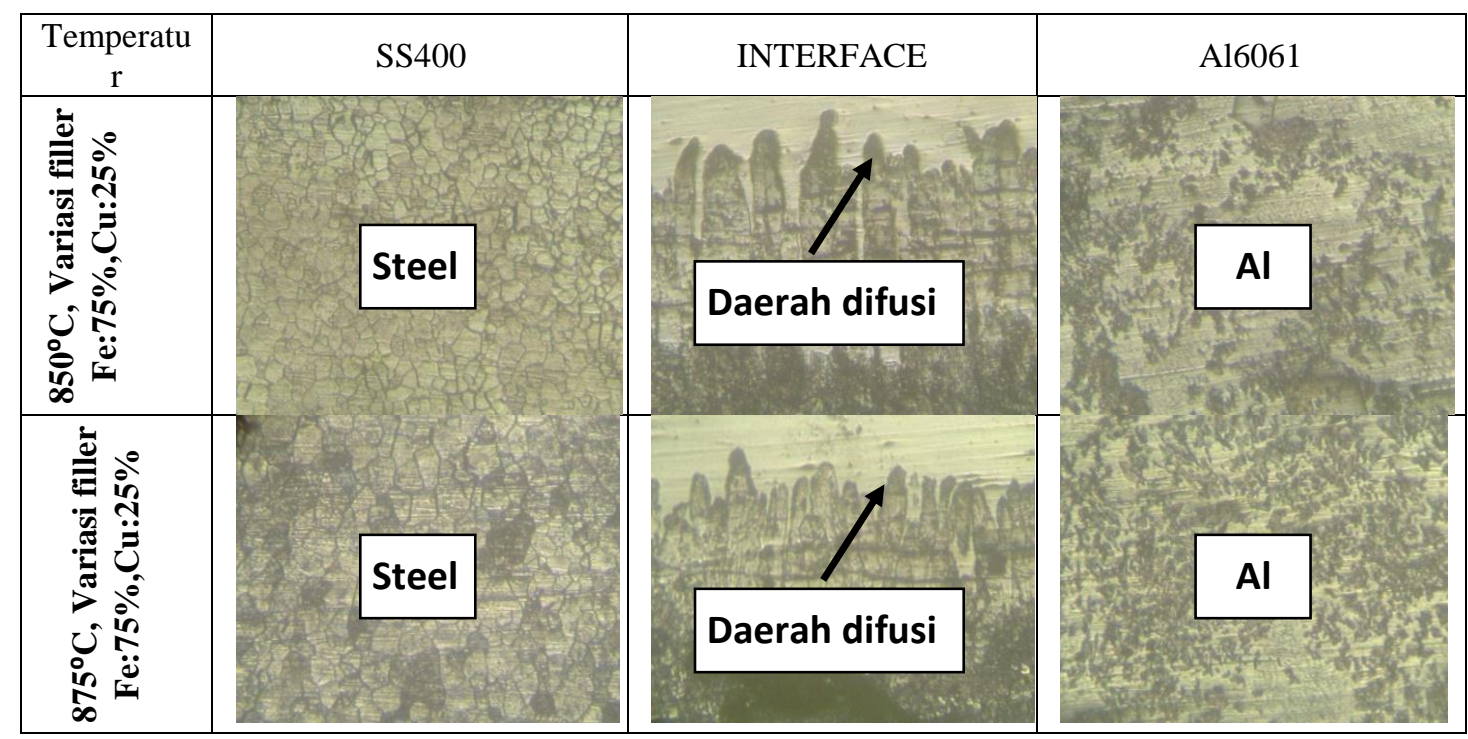




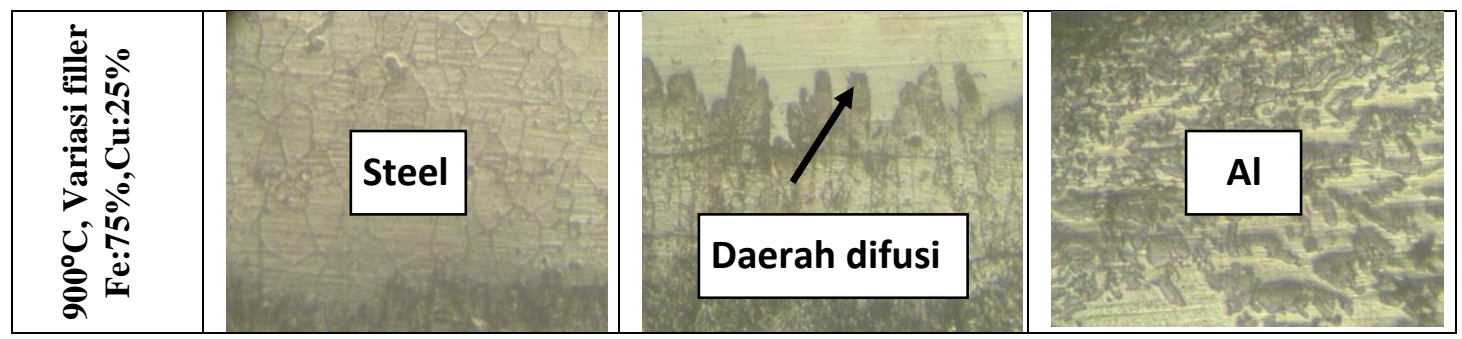

Gambar 7: Struktur mikro SS400, Interface, Al6061

\subsection{Analisa Uji Geser Tarik}

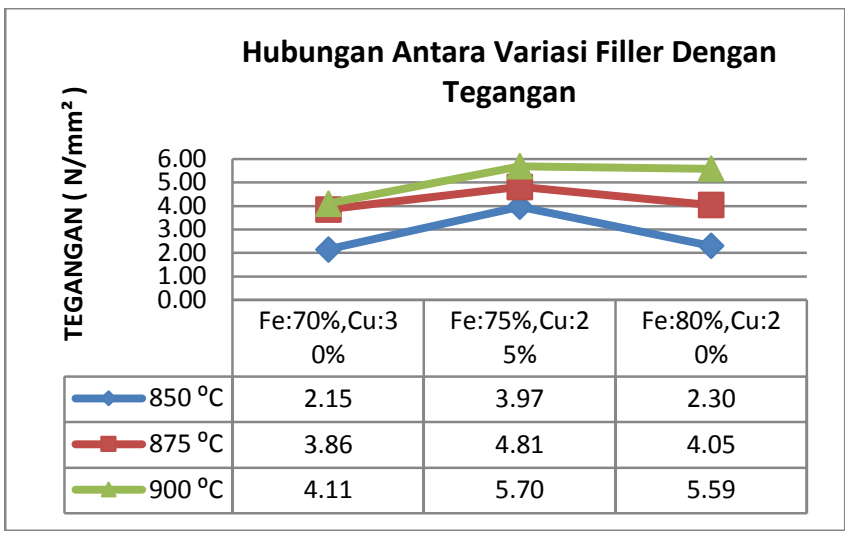

Gambar 8. Hubungan Antara Variasi Filler Dengan Tegangan

Hasil pengujian geser tarik berdasarkan variasi temperatur, nilai hasil tegangan yang tinggi terjadi pada variasi filler $\mathrm{Fe}: 75 \%, \mathrm{Cu}: 25 \%$ (gambar 8). Hal ini dipengaruhi oleh proses pemanasan yang terus menerus, sehingga menyebabkan serbuk $\mathrm{Cu}$ akan bersifat keras, tapi rapuh[12]. Dengan pemanasan yang tinggi, serbuk Fe akan berdifusi dengan base metal aluminium dan serbuk Cu akan difusi dengan base metal SS400 dan Al6061. Sehingga atom Fe dan $\mathrm{Cu}$ akan berikatan dengan base metal yang mempengaruhi sifat mekanik (Gambar 9).

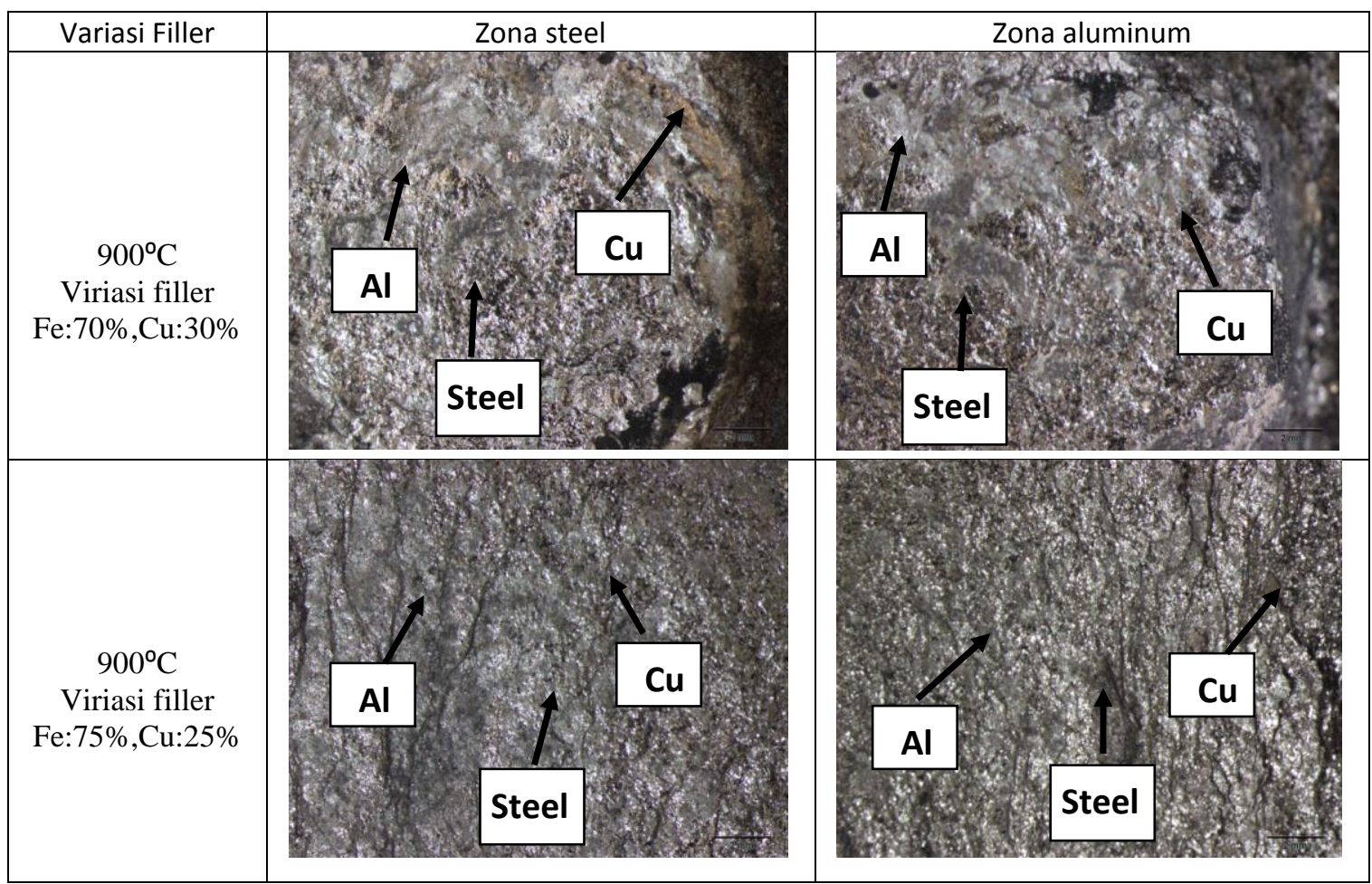




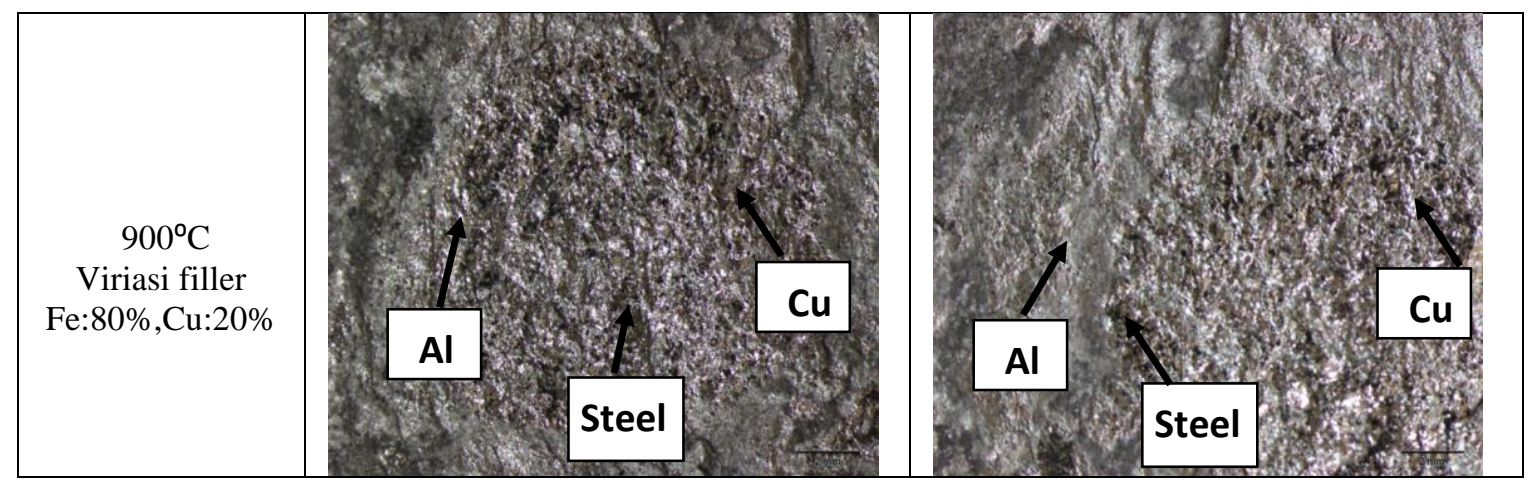

Gambar 9. Struktur makro uji geser tarik

\section{KESIMPULAN}

1) Diffusion welding disimilar metal antara SS400 dengan Al6061 menggunakan furnace induksi, dengan variasi temperatur dan variasi filler, menunjukkan adanya pembentukan lapisan intermetalic pada semua temperatur.

2) Hasil menurut Scanning Electron Microscop ( SEM ), proses difusi yang baik terjadi pada temperatur $850^{\circ} \mathrm{C}$ dengan variasi filler $\mathrm{Fe}: 75 \%, \mathrm{Cu}: 25 \%$.

3) Hasil distribusi kekerasan yang baik terjadi pada temperatur $900^{\circ}$ dengan variasi filler Fe:75\%,Cu:25\%.

4) Hasil pengujian geser tarik, nilai tegangan yang tinggi terjadi pada temperatur $900^{\circ} \mathrm{C}$ dengan variasi filler Fe:75\%,Cu:25\%.

5) Perlakuan panas, difusi atom $\mathrm{Fe}$ dan $\mathrm{Cu}$, sangat mempengaruhi proses pembentukan lapisan intermetalic. Semakin tinggi perlakuan panas, pembentukan lapisan intermetalic semakin merata.

6) Peranan serbuk $\mathrm{Cu}$ merupakan langkah untuk mempermudah proses difusi yang dipengaruhi oleh perlakuan panas. Semakin tinggi perlakuan panas, sifat $\mathrm{Cu}$ semakin keras dan rapuh. Sehingga akan berpengaruh pada kekerasan lapisan intermetalic. Dengan proses pemanasan yang tinggi, struktur mikro pada lapisan intermetalic semakin rapat dan merata. Semakin rapat dan merata susunan lapisan intermatalic berpengaruh pada sifat mekanik.

\section{REFERENSI}

[1] Dulal C. and Yeong Do Park.,2011. A Review on Al-Al/Al-Steel Resistance Spot Welding Technologies for Light Weight Vehicles. Journal of KWJS, Vol.29,No.4,pp397-402.

[2] Rathod M.J. and Kutsuna M.,2004. Joining of Aluminum Alloy 5052 and Low Carbon Steel by Laser Roll Welding, Welding Journal. 16-S.

[3] Sun X., Stephens, M.A.E.V., Khaleel, H., Shao, and Kimchi, M.,2004. Resistance Spot Welding of Aluminum Alloy to Steel with Transition Material From Process to Performance. Part I:Experimental Study. Welding Journal. 188-S.

[4] Sun X., and Khaleel, M.A., Resistance Spot Welding of Aluminum Alloy to Steel with Transition Material. Part II:Finite Element Analyses of Nugget Growth. Welding Journal. 197-S.

[5] Ranfeng Qiu a, Shinobu Satonaka, Chihiro Iwamoto,2009. Effect of interfacial reaction layer continuity on the tensile strength of resistance spot welded joints between aluminum alloy and steels, Material and Design 30, 3686-3689.

[6] Aizawa T.,Kashani M., and Okagawa.,2007. Application of Magnetic Pulse Welding for Aluminum Alloys and SPCC Steel Sheet Joints. Welding Journal,Vol.86,119-s-124-s.

[7] Shigeaki Kobayashi, Takao Yakou.,2002. Control of intermetallic compound layers at interface between steel and aluminum by diffusion-treatment. Materials Science and Engineering A338 (2002) 44-53

[8] Mahendran G. , Balasubramanian V., Senthilvelan T.,2010. Influences of diffusion bonding process parameters on bond characteristics of $\mathrm{Mg}-\mathrm{Cu}$ dissimilar joints, Transaction of Nonferrous Metal Society of China 20(2010) 997-1005.

[9] William D. Callister J.R,2001. Fundamentals of Materials Science and Engineering an interacrive, fifth edition.126-132.

[10] Triyono, Yustiasih P, dan Ikwal C. 2013. Critical Nugget Diameter of Resistance Spot Welded Stiffened Thin Plate Structure. Modern Applied Science. Vol 7,No.7,17-22.

[11] Aluminium 6061 data sheet.

[12] Gusti randa atmajaya.2011.Analisis Sifat Mekanik Penambahan Unsur Cu Pada Coran Alumuniu. Tugas akhir.

[13] Dinaharan K, Kalaiselvan, Vijay SJ, dan Raja P. 2012. Effect of Material Location and Tool Ratational Speed on Microstructure and Tensil Strength of Dissimilar Friction Stir Welded Aluminium Alloy. Archives of Civil and Mechanical Engineering. 12, 446-456.

[14] Chunzhi xia, dkk.2008. Microstructure and phase constitution near the interface of Cu/Al vacuum brazing using 
Al-Si filler metal. Science direct, vacum 82 (2008) 799-804.

[15] Tata Surdia,Shinroku Saito.1999.Pengetahuan Bahan Teknik.Cetakan Keempat.69-142.

[16] Harsono Wiryosumarto dan Toshi Okumura.1981.Teknologi Pengelasan Logam.Pradnya Paramita.113-126.

\section{UCAPAN TERIMA KASIH}

Penulis mengucapkan terima kasih atas dukungan dana dari Menteri Pendidikan Dan Kebudayaan Republik Indonesia melalui hibah MP3EI dengan kontrak No.499/UN.27.11/PN/2014 